\title{
Reverse vertical migration and hydrographic distribution of Anomalocera ornata (Copepoda: Pontellidae) in the US South Atlantic Bight
}

\author{
Patricia A. Tester ${ }^{1}$, Jonathan H. Cohen ${ }^{2}$, Guillermo Cervetto ${ }^{1}$ \\ ${ }^{1}$ Center for Coastal Fisheries and Habitat Research, National Ocean Service, NOAA, 101 Pivers Island Road, Beaufort, \\ North Carolina 28516, USA \\ ${ }^{2}$ Duke University Marine Laboratory, 135 Duke Marine Lab Road, Beaufort, North Carolina 28516, USA
}

\begin{abstract}
The vertical and horizontal abundance of juvenile and adult stages of the pontellid copepod Anomalocera ornata was determined on cruises of the 'Oregon II' during February 1991 and 1994 at coastal, shelf and Gulf Stream-influenced stations in Onslow Bay, North Carolina, USA. The presence and patterns of diel vertical migration (DVM) in this species, as well as its hydrographic habitat, were inferred from these data. Juveniles exhibited twilight vertical migration with residence in the upper water column at night, whereas adults had a reverse vertical migration pattern with residence in surface water during the day. The hydrographic distribution of $A$. ornata is primarily limited to the colder waters of coastal and shelf regions, with very few copepods present in warmer water influenced by the Gulf Stream. Given the hydrographic structure of Onslow Bay during the winter months, undergoing any DVM pattern could aid in retaining this species inshore.
\end{abstract}

KEY WORDS: Diel migration · Frontal zone $\cdot$ Horizontal and vertical abundance

\section{INTRODUCTION}

Copepods of the family Pontellidae are common members of zooplankton assemblages in continental shelf waters. Despite their seasonal abundance, there are few distributional records for these animals in shelf regions of the United States except for the Gulf of Mexico (e.g. Fleminger 1956, Turner et al. 1979, Turner \& Collard 1980). Many pontellid species seem to have distinct temperature-salinity associations (Bowman 1971). Accordingly, their surface distribution appears to parallel surface hydrographic features, leading to the suggestion that these copepods can be used as biological indicators of water masses (Sherman 1963, 1964). Pontellid distributions have been used effectively to delineate the region of mixing between coastal and oceanic surface waters (Sherman \& Schaner 1968), but the general utility of this approach is limited due to a lack of information on the hydrographic preferences of pontellid species.
Pontellids are typically classified as neustonic copepods (Wilson 1932, Hempel \& Weikert 1972, Turner et al. 1979, Turner \& Collard 1980), but a few observations have documented diel vertical migration (DVM) behavior in some pontellid species. Sherman (1963) found substantial day-night variation in the abundance of Labidocera spp., Pontella spp., Pontellopsis spp., and Pontellina spp. in the central north Pacific. In a survey of pontellid copepods in the neuston of the eastern Gulf of Mexico, Turner et al. (1979) noted an apparent DVM for several species: Calanopia americana, Labidocera scotti, Pontella atlantica, Pontellina perspicax and P. plumata. While most of these species were only present in night samples, Pontella atlantica was only collected during the day.

The most common pattern of DVM is an ascent in the water column to minimum depth around sunset and descent to maximum depth around sunrise, termed nocturnal or normal DVM (Forward 1988). However, it is reverse DVM, an ascent to shallow water at sunrise 
followed by a descent to deeper water at sunset, which could explain the observations of 'neustonic habitat' for some of the Pontillidae. A third pattern, twilight DVM, involves an ascent to the surface at sunset, a descent to deeper water around midnight (i.e. the 'midnight sink'), followed by a second ascent to the surface and then descent to deeper water at sunrise. There is variability in the pattern expressed for any given species at a particular place and time, which is probably related to plasticity in the behavioral responses copepods exhibit under variable ambient predation pressures (e.g. Bollens \& Frost 1989a,b, Ohman 1990) or environmental conditions.

Anomalocera ornata Sutcliffe (1949) is a large ( $4.0 \mathrm{~mm})$, blue-pigmented, omnivorous pontellid copepod (Turner 1991) capable of feeding on phytoplankton, zooplankton, and fish eggs and larvae (Herring 1965, Turner et al. 1985). It is a patchily distributed, but abundant, component of the winter neuston of the continental shelf of the US South Atlantic Bight (SAB) and Gulf of Mexico (Bowman 1971, Turner \& Collard 1980), where it forms large aggregations (Christmas 1968). It has a distinctly seasonal occurrence; adults are abundant between February and March. Females can either produce subitaneous eggs, which hatch immediately, or produce eggs that undergo a summer diapause cycle, hatching the following September (McCrary 1978).

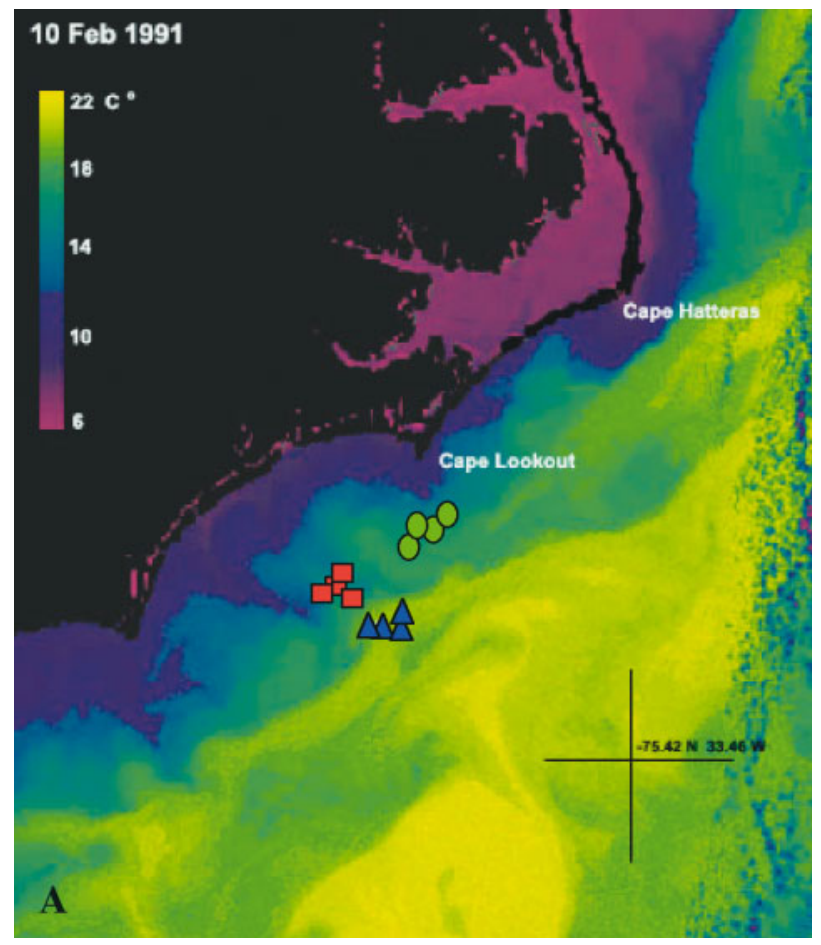

In the present study, we enumerated Anomalocera ornata in depth-stratified field samples collected throughout the diel light cycle from sites in coastal, shelf and Gulf Stream-influenced regions. The vertical distribution of adult and juvenile copepods in the water column was analyzed with respect to time of day and hydrographic location. These data were used to infer the presence of reverse DVM in adult $A$. ornata and twilight DVM in juveniles, as well as to identify the hydrographic habitat of this species as primarily limited to coastal and shelf waters.

\section{MATERIALS AND METHODS}

Plankton samples were collected on the NOAA vessel 'Oregon II' cruises at 12 stations between 5 and 10 February 1991 and 14 stations between 1 and 6 February 1994 in the region of $33^{\circ} 47^{\prime} \mathrm{N}$ to $34^{\circ} 18^{\prime} \mathrm{N}$, $76^{\circ} 29^{\prime} \mathrm{W}$ to $76^{\circ} 58^{\prime} \mathrm{W}$ in Onslow Bay, North Carolina, USA (Fig. 1). These stations were selected as they spanned a hydrographic gradient: inshore coastal water, frontal shelf water, and offshore water influenced by the Gulf Stream, as determined during the cruises by sea surface temperature (advanced very high resolution radiometry, AVHRR) imagery and CTD casts.

The catches of large pontillid copepods were incidental to the main purpose of the cruises. The sam-

Fig. 1. Sea surface temperature (AVHRR) images for Onslow Bay, North Carolina, overlaid with coastal (green circles), shelf (red squares), and Gulf Stream (blue triangles)-influenced stations sampled during (A) 1991 and (B) 1994 cruises of 'Oregon II'. Dashed lines in (B): transect lines from coastal water to the Gulf Stream used for analysis of Anomalocera ornata horizontal distribution 
pling design used during the cruises was optimized to examine the flux of winter-spawned larval fishes across the western Gulf Stream front south of Cape Hatteras, USA (see Govoni \& Spach 1999). However, because dense surface patches of large blue copepods, identified as Anomalocera ornata, were noted during these winter cruises, the copepods were sorted from the cruise samples after the larval fishes had been removed. The physical structure of the water column was reconstructed from temperature and salinity profiles obtained with a temperature, salinity, and depth recorder (Applied Microsystems). The cruise designation of stations as coastal-, shelf- or Gulf Streaminfluenced was reevaluated based on $\sigma_{t}$ values calculated from temperature and salinity measurements made at $5 \mathrm{~m}$ depth. Values for $\sigma_{\mathrm{t}}$ were relatively constant with depth and, by $5 \mathrm{~m}$, surface anomalies from the instrument were no longer apparent. Water types were compared statistically using 1-factor ANOVAs for 1991 and 1994 data. Post hoc tests were done using the Newman-Keuls method for unequal sample sizes (Zar 1999). For a general summary of the wind conditions during the sampling periods, hourly averages of wind speed, wind direction, air temperature, and atmospheric pressure for the days of each cruise were obtained from the NOAA National Data Buoy Center (NDBC) (www.ndbc.noaa.gov) and were used to calculate wind stress (Large \& Pond 1981, Blanton et al. 1989). The closest NDBC station to our sampling sites with data for both February 1991 and 1994 was Cape Lookout, North Carolina (Stn CLKN7) (Fig. 1). For a finer scale assessment of wind conditions during sampling, wind speed and direction were obtained from the bridge log of the 'Oregon II'. Statistical comparisons between years were done for the bridge log data; wind speed was compared using a $t$-test, and wind direction was compared using Watson's F-test (Zar 1999).

During the 1991 cruise, 4 stations were sampled within each hydrographic region (coastal, shelf and Gulf Stream-influenced). At each station, MOCNESS tows (333 $\mu \mathrm{m}$ mesh; Wiebe et al. 1976) were made at $5 \mathrm{~m}$ depth intervals throughout the water column $(0-35 \mathrm{~m})$ at 1 of 4 times during the diel light cycle (7:00, $12: 00,18: 00$, and 24:00 h). Tow volumes ranged from 98 to $400 \mathrm{~m}^{3}$ (average $=146 \mathrm{~m}^{3}$ ). In 1991, each hydrographic region was sampled during each quarter of the diel light cycle (approximate times of sunrise and sunset were 7:00 and 17:45 h, respectively). During the 1994 cruise, stations were sampled along 2 cross-shelf track lines at various times. Tow volumes ranged from 90 to $617 \mathrm{~m}^{3}$ (average $=142 \mathrm{~m}^{3}$ ). Only data from 1991 were used to analyze DVM behavior as these samples were evenly distributed among hydrographic regions over the diel light cycle. The 1994 data were used to evaluate differences in copepod abundance among hydrographic regions by Kruskal-Wallis 1-factor ANOVAs; Dunn's method was used for post hoc tests, as group sizes were not equal (Zar 1999). A nonparametric test was used as the assumptions of normality and equal variance could not be met.

A total of 164 samples were preserved in 95\% buffered ethanol. Anomalocera ornata were sorted either from the entire sample, or a 1:1 split was made using a Folsom plankton splitter. Copepodites (CI-CV) and adults (CVI) were separated, sexed (late-stage copepodites-CVI), and counted. No naupliar stages of this species were found. It is likely that $A$. ornata nauplii fail to be retained by the $333 \mu \mathrm{m}$ mesh; alternatively they may have been absent from the water column during both sampling periods.

\section{RESULTS}

\section{Diel vertical migration}

A reverse DVM pattern was observed for adults (Fig. 2A). No differences in the vertical distribution of males and females were found within each ontogenetic group; therefore both sexes were combined for subsequent analysis. The abundance of adults at each depth was low ( 0 to 0.78 copepods $\mathrm{m}^{-3}$ ). Adult Anomalocera ornata were only found at coastal stations, with the exception of 7 individuals in the 5-10 $\mathrm{m}$ depth range of the $12: 00 \mathrm{~h}$ shelf station $(<2 \%$ of the total copepods collected at that time at all stations). Accordingly, the following analysis is limited to coastal stations. At sunrise $(7: 00 \mathrm{~h})$, adult $A$. ornata were concentrated between 10 and $20 \mathrm{~m}$. During the day, copepods appear to rise to the surface, as the adult population distribution at noon (12:00 h) was narrow and centered between 0 and $5 \mathrm{~m}$. At sunset $(18: 00 \mathrm{~h}), 2$ peaks in abundance were evident: 1 at the surface (0-5 m) and one at depth (10-15 m). At midnight, adult $A$. ornata were deep in the water column $(>10 \mathrm{~m})$.

Juvenile abundance at each depth was greater than for adults (0 to 3.02 copepods $\mathrm{m}^{-3}$ ). While copepodites were found in all hydrographic regions, coastal stations had the greatest number. In contrast to the reverse DVM pattern exhibited by adult Anomalocera ornata, either a nocturnal or a twilight pattern was present in juveniles (Fig. 2B). At sunrise (7:00 h), juvenile abundance was greatest in the upper portion of the water column $(>10 \mathrm{~m})$. By noon $(12: 00 \mathrm{~h})$ juveniles were found deep in the water column, primarily between 5 and $20 \mathrm{~m}$. At sunset (18:00 h), juvenile abundance in coastal water was greatest in the upper $5 \mathrm{~m}$, while in shelf water abundance was greatest at depth (25-30 m). Juveniles were distributed broadly throughout the water column at midnight (24:00 h). 


\section{$\rightarrow$ Coastal $\multimap-$ Shelf $\rightarrow$ - Gulf Stream-influenced}

A Adults

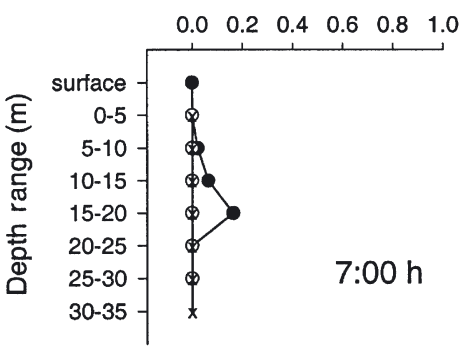

B Juveniles

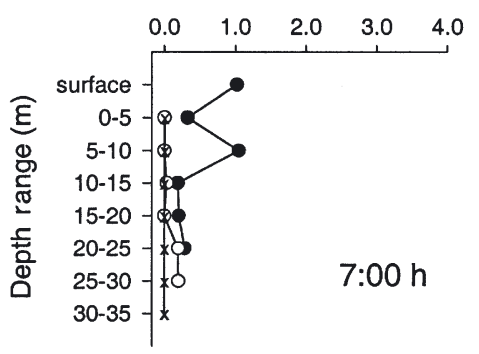

\section{A. ornata abundance (copepods $\mathrm{m}^{-3}$ )}
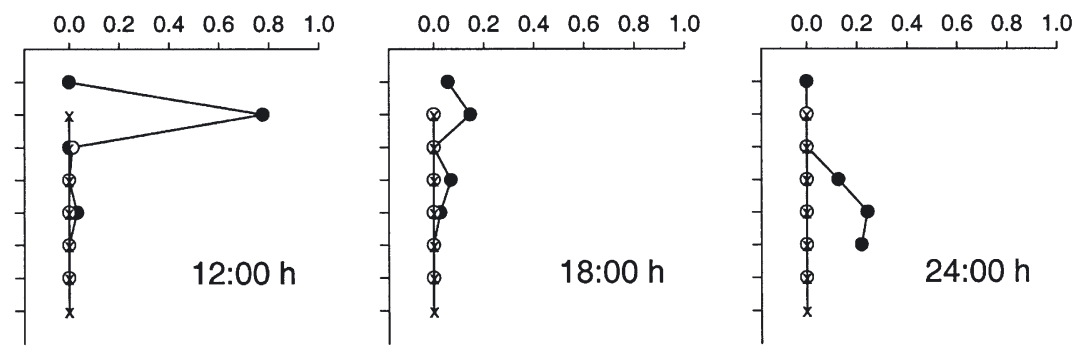

A. ornata abundance (copepods $\mathrm{m}^{-3}$ )
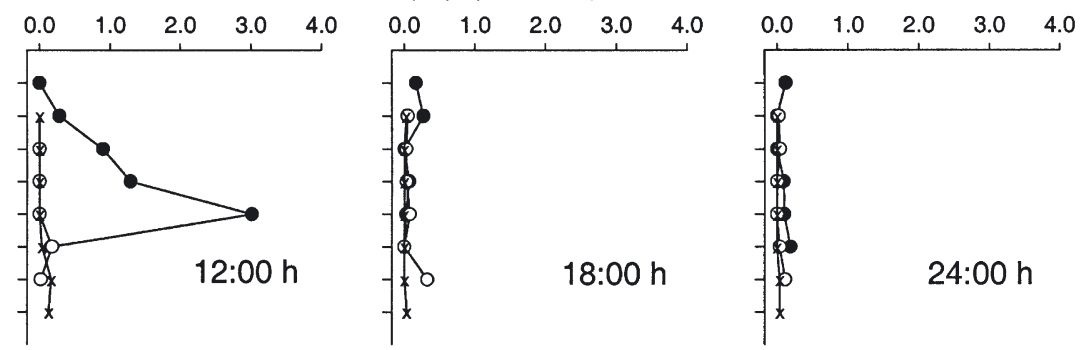

Fig. 2. Anomalocera ornata. Diel vertical distribution during 1991 cruise. Abundance of (A) adult and (B) juvenile copepods $\mathrm{m}^{-3}$ for each MOCNESS depth range at 4 sampling times: 7:00, 12:00, 18:00, and 24:00 h, showing profiles for coastal, shelf, and Gulf Stream-influenced stations. Adult A. ornata were only found at coastal stations, with the exception of the 12:00 h shelf station in the 5-10 $\mathrm{m}$ depth range

\section{Hydrography of sampling area}

Differences in $\sigma_{t}$ values were found among coastal-, shelf- and Gulf Stream-influenced sites sampled in $1991\left(F_{2,10}=76.925, \mathrm{p}<0.001\right)$. There was little distinctiony hydrographically between the coastal and shelf stations during the 1991 cruise, when $\sigma_{t}$ values were between 26.0 and $26.5 \mathrm{mg} \mathrm{m}^{-3}$ for both coastal and shelf water types (Neuman-Keuls, $q=1.217, \mathrm{p}=0.410$ ). Stations located in Gulf Stream-influenced water had significantly lower $\sigma_{\mathrm{t}}$ values, between 25.0 and $25.5 \mathrm{mg}$ $\mathrm{m}^{-3}$, relative to coastal and shelf stations $(q=15.513$, 15.315, p < 0.001) (Fig. 3A). In 1994, coastal, shelf and Gulf Stream-influenced water had significantly different $\sigma_{\mathrm{t}}$ values $\left(F_{2,10}=24.269, \mathrm{p}<0.001 ; q=9.506,7.053\right.$, 3.829, p < 0.05) (Fig. 3B).

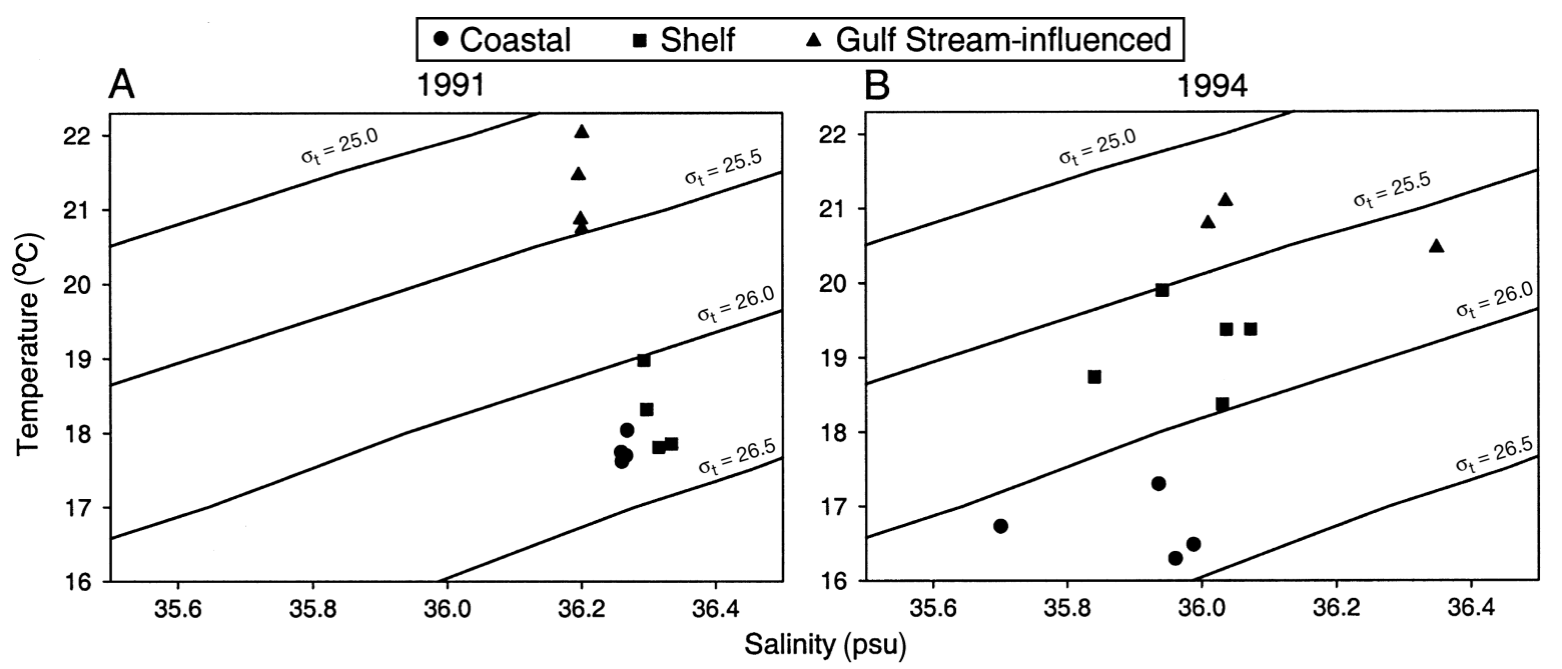

Fig. 3. Temperature and salinity plot of sites sampled during (A) 1991 and (B) 1994 cruises. Values plotted are from 5 m depth. Contour lines represent $\sigma_{\mathrm{t}}$ isopycnals $\left(\mathrm{mg} \mathrm{m}^{-3}\right.$ ). Hydrographic delineations (coastal, shelf, Gulf Stream-influenced) were based on CTD and sea surface temperature (AVHRR) imagery 

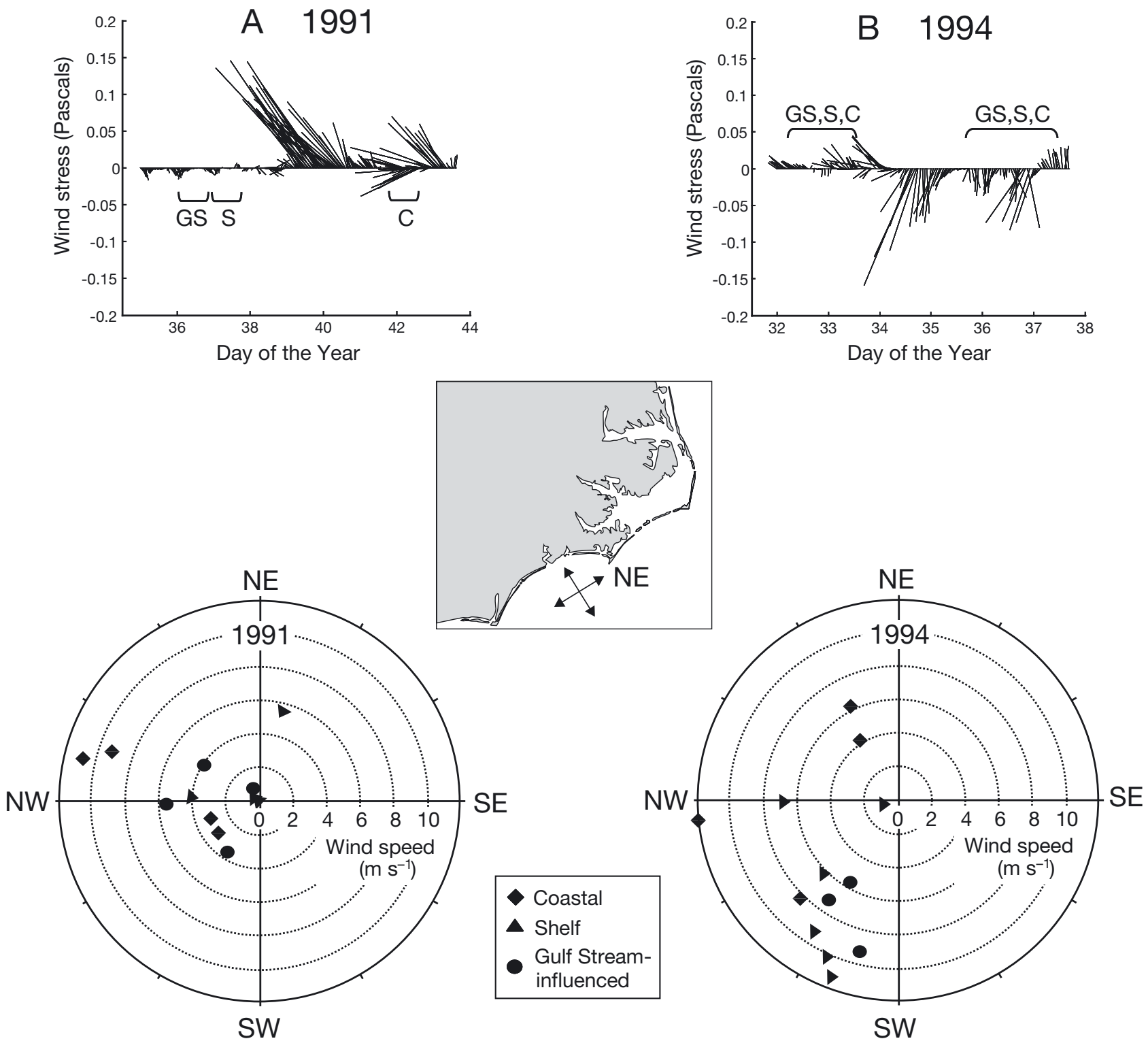

Fig. 4. Wind stress and speed during (A) 1991 and (B) 1994 sampling periods. For interpretation of wind data relative to shoreline south of Cape Lookout (Onslow Bay), wind direction was rotated 56 ${ }^{\circ}$ clockwise (Govoni \& Pietrafesa 1994). Upper panels show wind stress throughout entire sampling period each year for Cape Lookout NDBC station (CLKN7); vector lengths indicate wind stress (pascals), vector directions indicate direction from which wind blew (degrees, clockwise from northeast along shore), time periods of sampling in each hydrographic region are indicated on each plot (GS: Gulf Stream-influenced; S: shelf; C: coastal). Lower panels show wind speed $\left(\mathrm{m} \mathrm{s}^{-1}\right.$ ) and direction (degrees, clockwise from northeast along shore) recorded at each sampling station as reported in 'Oregon II's' weather-log

Wind conditions differed significantly between 1991 and 1994 (Fig. 4). Wind speed at the sampling stations was greatest in 1994 ( $t$-test, $t_{23}=2.587, \mathrm{p}<0.05$ ), and the mean direction from which the wind blew shifted $\left(F_{21}=5.37, \mathrm{p}<0.05\right)$, as northwesterly wind from the shore occurred in 1991 (mean angle $=285^{\circ}$, $\mathrm{p}<0.05$, Rayleigh's test) while the wind was more westerly in 1994 (mean angle $=235^{\circ}, \mathrm{p}<0.05$, Rayleigh's test).

\section{Copepod abundance among hydrographic regions}

Two transects from coastal water to the Gulf Stream (1994) provided the data for horizontal distribution of juvenile and adult Anomalocera ornata. Copepod abundance was significantly different among coastal, shelf and Gulf Stream-influenced stations. Adults were significantly more concentrated in coastal water than in either shelf or Gulf Stream-influenced water 


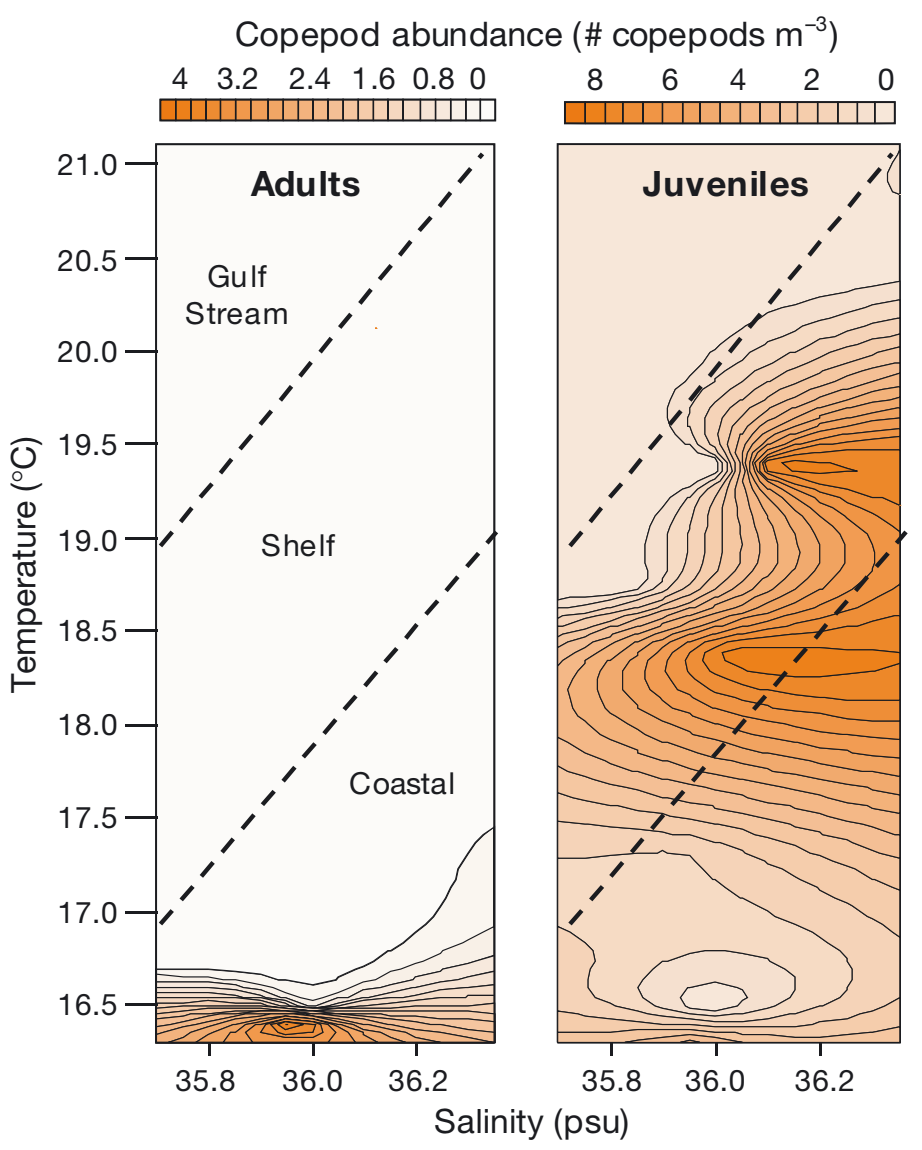

Fig. 5. Copepod distribution among hydrographic regions during 1994 cruise. Copepod abundance $\left(\mathrm{m}^{-3}\right)$ was summed throughout water column and contours were plotted as a function of temperature and salinity at $5 \mathrm{~m}$ at each station. Dashed lines: $\sigma_{t}$ isopycnals delineating the hydrographic regions in Fig. 3B

(Kruskal-Wallis $H=26.266$, df $=2$, p $<0.001$; Dunn's $Q=3.797,3.687, \mathrm{p}<0.05$ ) (Fig. 5), with no difference between adult abundance in shelf and Gulf Streaminfluenced water $(Q=0.446, \mathrm{p}>0.05)$. Juvenile $A$. ornata, which were more abundant than adults in all hydrographic regions, especially shelf water, were only present in significantly greater abundance in coastal water relative to Gulf Stream-influenced water $(H=17.072, \mathrm{df}=2 ; Q=3.845, \mathrm{p}<0.05)$ (Fig. 5)

\section{DISCUSSION}

While most pontellid copepods are assumed to be non-migratory surface dwellers (e.g. Turner et al. 1979), the vertical distribution of Anomalocera ornata during the 1991 cruise (Fig. 2) suggests that adults were undergoing reverse diel vertical migration (DVM). Since the expression of DVM by zooplankton is variable (e.g. Bollens \& Frost 1989b), these organ- isms may exhibit other migration patterns, or lack this behavior, at other locations and times. However, adult A. ornata are consistently found in daytime flood-tide plankton samples inshore of Beaufort Inlet (North Carolina), during winter months, yet are absent from similar samples collected during nighttime flood tides (J. Cohen pers. obs.), suggesting that reverse DVM may be a common behavior for this species.

An alternative hypothesis that could explain differences in vertical abundance of copepods at different phases of the diel light cycle is that copepods rapidly respond to turbulence cues created by short periods of high wind stress (Haury et al. 1990, Incze et al. 2001). Incze et al. (2001) reported that copepodites of several coastal species rapidly descended in the water column in response to a short $(<10 \mathrm{~h})$ wind event with wind speeds of $10 \mathrm{~m} \mathrm{~s}^{-1}$. During the majority of sampling events in 1991 (8 of 12), wind speed was $4 \mathrm{~m} \mathrm{~s}^{-1}$ or less. On only 2 occasions was the wind speed near $10 \mathrm{~m} \mathrm{~s}^{-1}$, both occurring during sampling at coastal sites (Fig. 4). During these 2 windy periods, the vertical distribution of Anomalocera ornata (7:00 and 12:00 h) did not appear to be affected by the wind. Juveniles were close to the surface during 1 wind event $(7: 00 \mathrm{~h})$, and deeper during the other (12:00 h), while adults had the opposite vertical distribution during these wind events (deep at 7:00 $\mathrm{h}$ and shallow at 12:00 h) as would be predicted by the migration patterns described.

There is increasing laboratory and field evidence that DVM in zooplankton is induced rapidly by the presence of fishes, and therefore is an inducible defense that serves primarily in the avoidance of these visual predators (Bollens \& Frost 1989a,b, Hays et al. 1994, Ringelberg 1999, Forward \& Rittschof 2000). Since Anomalocera ornata is a relatively large copepod $(\sim 4 \mathrm{~mm})$, and fishes tend to feed selectively on larger zooplankton (e.g. Brooks \& Dodson 1965), this species could be quite vulnerable to predation by fishes at the surface during the day. Accordingly, we reviewed the possibilities of either adult or larval fish predation. The most abundant fishes in coastal water of the SAB during winter are estuarine-dependent species migrating offshore to spawn (Miller et al. 1984): spot Leiostomus xanthurus, Atlantic croaker Micropogonias undulatus, pinfish Lagodon rhomboides, and Atlantic menhaden Brevoortia tyrannus. Menhaden, unique among these fish species in being primarily planktivorous feeders, have been the most extensively studied (Reintjes 1969, Lewis \& Peters 1994). Menhaden do eat copepods, but they actively avoid large crustacean zooplankton in favor of smaller copepod nauplii and adults (Reintjes 1969, Durbin \& Durbin 1975). Given the size and speed of planktonic $A$. ornata, it is unclear as to the extent to which adult fishes offshore would prey on these copepods, espe- 
cially in view of Hempel \& Weikert's (1972) findings that adult fishes primarily feed in lower light conditions of deeper water.

Larval fishes, however, need more light to capture prey and are commonly present near the surface during the day. Govoni \& Spach (1999) found that the total larval fish abundance in the same 1991 trawl samples that are used here to report Anomalocera ornata numbers, was low $\left(<0.13\right.$ larvae $\mathrm{m}^{-3}$ at $12: 00 \mathrm{~h}$ above $\left.20 \mathrm{~m}\right)$. Their data indicated that larvae were most abundant around $20 \mathrm{~m}$ at night $\left(<1.0\right.$ larvae $\left.\mathrm{m}^{-3}\right)$, not at the surface during the day.

Additionally, based on studies of larval fish gut contents (e.g. Govoni et al. 1983, Baier \& Purcell 1997), it is unlikely that larval fishes in coastal water can consume prey as large as adult Anomalocera ornata. In fact, there is laboratory evidence that the opposite predation scenario may occur: adult $A$. ornata are capable of grasping and completely consuming yolk-sac and firstfeeding Brevoortia tyrannus larvae in less than $4 \mathrm{~min}$ (Turner et al. 1985). Predation on fish larvae by $A$. ornata in nature has not been reported, but invertebrate predation has been suggested as a potentially important source of larval fish mortality (Lillelund \& Lasker 1971, Bailey \& Yen 1983).

Reverse migration is generally thought of as a defense against vertically migrating predators, often invertebrates, which themselves are undergoing nocturnal DVM as a defense against diurnal fish predators. This situation has been most clearly documented in the marine environment for the copepod Pseudocalanus spp., which undergoes reverse DVM when predatory copepods, chaetognaths, and euphausids are present and are migrating nocturnally (Ohman et al. 1983). Chaetognaths, not visual predators, may be a factor in the reverse DVM pattern seen in adult Anomalocera ornata in the SAB. Here, the winter chaetognath abundance can be as great as 30 to 40 chaetognaths $\mathrm{m}^{-3}$ and the dominant chaetognath Sagitta enflata $(61 \%)$ is also the largest species in the region, (up to $14 \mathrm{~mm}$; Coston-Clements 1980). Based on $S$. enflata head width, this species should be capable of capturing prey in a size range of 0.1 to $1.1 \mathrm{~mm}$ body width, which would include $A$. ornata adults.

While adult Anomalocera ornata had a distinct reverse diel vertical migration pattern, the distribution of juvenile $A$. ornata differed markedly from adults in that either nocturnal or twilight DVM behavior was observed. Juveniles were most abundant in deep water during the day, were relatively evenly distributed at sunset and throughout the night, and then rose to the surface again at sunrise. If $A$. ornata copepodites were undergoing nocturnal DVM, abundance in surface waters should increase at sunset and remain high throughout the night. Because copepods were present throughout the water column at midnight, it is possible that twilight DVM was occurring, with this distribution indicative of a 'midnight sink'. Ontogenetic changes in zooplankton DVM, both in the overall presence of the behavior as well as in the specific pattern exhibited, are common (e.g. Cronin \& Forward 1986, Osgood \& Frost 1994, Hays 1995). As copepods develop, the suite of predators that can successfully feed on them changes, and therefore predator avoidance behaviors such as DVM may change accordingly. While adult $A$. ornata appear too large and fast for larval fishes to capture and ingest, juvenile copepods may be vulnerable to these predators. From an ultimate evolutionary perspective it is unlikely that a predator avoidance behavior such as DVM would remain fixed during development to the adult stage (Neill 1992). From a proximate physiological perspective, morphological and physiological changes that could influence DVM often occur with ontogeny (e.g. photobehavior, Forward \& Costlow 1974).

Reverse DVM places adult copepods in shallow water during the day, vulnerable to photo-oxidative damage by UV light as well as visual predators. Carotenoid pigments may afford Anomalocera ornata some protection from harmful wavelengths of light (e.g. Hairston 1979). Indeed, many neustonic species appear to have a similar blue coloration, although high pigmentation is not always correlated with surface residence (Hempel \& Weikert 1972, Hays et al. 1994). In addition to protection from photo-oxidation, its blue-green pigmentation may also serve to camouflage $A$. ornata from predators by reflecting wavelengths similar to those that dominate in their coastal habitat $(500-550 \mathrm{~nm}$; Forward et al. 1988), reducing the contrast of the copepods against upwelling and horizontal background light. Seabirds, particularly zooplanktivorous phalaropes (Dodson \& Egger 1980), may prey on adult A. ornata in surface waters. Haney \& McGillivary (1985) reported phalaropes to be most abundant in the SAB during the winter months, where they occur primarily on the shoreward side of frontal zones. This spatio-temporal distribution is similar to that found for adult $A$. ornata in the present study (Fig. 5). By employing a mechanism of camouflage that reduces contrast when viewed from above, adult $A$. ornata may have some ability to hide from avian predators (e.g. Hamner 1996).

Apart from the effects of biological factors on the distribution and abundance of Anomalocera ornata, physical models and empirical data for layered water circulation in Onslow Bay during winter months suggest that any DVM pattern (nocturnal, reverse or twilight) would facilitate retention of zooplankton in coastal water and prevent their being transported offshore, provided migration occurs between surface and deep currents (Miller et al. 1984, Checkley et al. 1988, 
Govoni \& Pietrafesa 1994). It is possible that adult $A$. ornata are able to avoid transport offshore while also taking advantage of surface irradiance for vision during the day through reverse DVM. A. ornata have well-developed naupliar eyes with lens optics to focus light on retinular cells (e.g. Vaissière 1961). The wavelengths of light to which A. ornata respond behaviorally are limited to the blue-green region; this spectral sensitivity matches the ambient wavelengths that occur during the times of migration (twilight) in coastal water (Cohen \& Forward 2002). That these copepods have highly evolved lens optics, with distinct sexual dimorphism in the presence and size of the lenses (J. Cohen pers. obs.), suggests an important role for vision in A. ornata behavior (e.g. DVM, feeding, and mate-recognition). The observed reverse DVM pattern would place these copepods in a light environment adequate for vision during the day, while also allowing them to maintain their horizontal position over the continental shelf without being transported too far inshore or offshore. Juvenile A. ornata undergoing twilight DVM would also be retained in coastal water, but by avoiding surface waters during the day would gain a refuge from visual predators.

It has been suggested that pontellid copepods can be used as water mass indicators because their surface distributions appear to parallel surface hydrographic features (Sherman 1963, 1964). During the 1994 cruise, both juvenile and adult Anomalocera ornata were more abundant in coastal water than in Gulf Streaminfluenced water, with large numbers of juveniles also being found in shelf water. In 1994, stations clearly fall into 3 distinct water types based on their temperaturesalinity relationships (coastal, shelf and Gulf Streaminfluenced). Coastal water was the coolest and least saline; Gulf Stream influenced water was the warmest and most saline, while shelf water was intermediate in terms of temperature and salinity. A. patersoni, a congener of $A$. ornata, has likewise been reported most commonly in coastal water, with abundance decreasing across a frontal region in the Gulf of Maine (Sherman \& Schaner 1968). Sherman \& Schaner (1968) used the surface distribution of pontellids to infer incursions of the Gulf Stream over their study area. Our data suggest that adult $A$. ornata, as well, may be a useful indicator species for coastal water.

The presence of adult Anomalocera ornata primarily in coastal water is consistent with their summer diapause cycle. If adult copepods inhabited shelf- and Gulf Stream-influenced water masses, then there would be increased risk of diapause eggs being advected away from the shelf region by Gulf Stream currents. Interestingly, A. patersoni also produces over-summering diapause eggs (Ianora \& Santella 1991). By having hydrographic distributions limited to coastal water, these congeneric species probably produce diapause eggs that sink to the sediments of the adult habitat and are available to hatch the following winter.

While these data clearly suggest adult Anomalocera ornata is a reverse migrator with a hydrographic distribution limited to coastal water masses, further observational studies would aid in confirming these vertical and horizontal patterns. The proximate physiological mechanisms underlying DVM have never been reported for a reverse migrator. A. ornata would be a useful species for both laboratory studies attempting to elucidate these mechanisms, and field studies correlating vertical distribution with environmental variables (e.g. light) that stimulate DVM-related swimming behavior.

Acknowledgements. S. Varnam helped in figure preparation and J. Hench provided the MATLAB code for processing the wind data. Dr. J. Govoni and L. Settle provided samples from cruises on the NOAA vessel 'Oregon II'. G. Cervetto was supported by the National Research Council postdoctoral program. Sea surface temperature imagery was provided by NOAA's COASTWATCH program. Drs Richard Forward, Jefferson Turner, Peter Verity and an anonymous reviewer provided helpful comments on the manuscript.

\section{LITERATURE CITED}

Baier CT, Purcell JE (1997) Trophic interactions of chaetognaths, larval fish, and zooplankton in the South Atlantic Bight. Mar Ecol Prog Ser 146:43-53

Bailey KM, Yen J (1983) Predation by a carnivorous marine copepod, Euchaeta elongata Esterly, on eggs and larvae of the Pacific hake, Merluccius productus. J Plankton Res 5:71-83

Blanton JO, Amft JA, Lee DK, Riordan A (1989) Wind stress and heat fluxes observed during winter and spring 1986. J Geophys Res 94:10 686-10 698

Bollens SM, Frost BW (1989a) Predator-induced diel vertical migration in a planktonic copepod. J Plankton Res 11: 1047-1065

Bollens SM, Frost BW (1989b) Zooplanktivorous fish and variable diel vertical migration in the marine planktonic copepod Calanus pacificus. Limnol Oceanogr 34:1072-1083

Bowman TE (1971) The distribution of calanoid copepods off the southeastern United States between Cape Hatteras and southern Florida. Smithson Contrib Zool 96:1-58

Brooks JL, Dodson DI (1965) Predation, body size, and composition of the plankton. Science 150:28-35

Checkley DM, Raman S, Maillet GL, Mason KL (1988) Winter storm effects on the spawning and larval drift of a pelagic fish. Nature 335:346-348

Christmas JY (1968) The occurrence of large shoals of Anomalocera ornata Sutcliffe (1949) (Crustacea: Copepoda) in Mississippi sound and adjacent Gulf of Mexico waters. J Miss Acad Sci 14:128-129

Cohen JH, Forward RB Jr (2002) Spectral sensitivity of vertically migrating marine copepods. Biol Bull (Woods Hole) 203:307-314

Coston-Clements L (1980) Preliminary studies on the role of chaetognaths as planktonic predators of marine fish larvae. ASB Bull 27:29

Cronin TW, Forward RB Jr (1986) Vertical migration cycles of 
crab larvae and their role in larval dispersal. Bull Mar Sci 39:192-201

Dodson SI, Egger DL (1980) Selective feeding of red phalaropes on zooplankton of Arctic ponds. Ecology 61: 755-763

Durbin AG, Durbin EG (1975) Grazing rates of the Atlantic menhaden Brevoortia tyrannus as a function of particle size and concentration. Mar Biol 33:265-277

Fleminger A (1956) Taxonomic and distributional studies on the epiplankton calanoid copepods (Crustacea) of the Gulf of Mexico, PhD dissertation Harvard University, Cambridge, MA

Forward RB Jr (1988) Diel vertical migration: zooplankton photobiology and behavior. Oceanogr Mar Biol Annu Rev 26:361-393

Forward RB Jr, Costlow JD Jr (1974) The ontogeny of phototaxis by larvae of the crab Rhithropanopeus harrisii. Mar Biol 26:27-33

Forward RB Jr, Rittschof D (2000) Alteration of photoresponses involved in diel vertical migration of a crab larva by fish mucus and degradation products of mucopolysaccharides. J Exp Mar Biol Ecol 245:277-292

Forward RB Jr, Cronin TW, Douglass JK (1988) The visual pigments of crabs. II. Environmental adaptations. J Comp Physiol A 162:479-490

Govoni JJ, Pietrafesa LJ (1994) Eulerian views of layered water currents, vertical distribution of some larval fishes, and inferred advective transport over the continental shelf off North Carolina, USA, in winter. Fish Oceanogr 3: 120-132

Govoni JJ, Spach HL (1999) Exchange and flux of larval fishes across the western Gulf Stream front south of Cape Hatteras, USA, in winter. Fish Oceanogr 8:77-92

Govoni JJ, Hoss DE, Chester AJ (1983) Comparative feeding of three species of larval fishes in the Northern Gulf of Mexico: Brevoortia patronus, Leistomus xanthurus, and Micropogonias undulatus. Mar Ecol Prog Ser 13: 189-199

Hamner WM (1996) Predation, cover, and convergent evolution in epipelagic oceans. In: Lenz PH, Hartline DJ, Purcell JE, Macmillan DL (eds) Zooplankton: sensory ecology and physiology. Gordon \& Breach, Amsterdam, p 17-35

Haney JC, McGillivary PA (1985) Midshelf fronts in the South Atlantic Bight and their influence on seabird distribution and seasonal abundance. Biol Oceanogr 3:401-430

Hairston NG Jr (1979) The adaptive significance of color polymorphism in two species of Diaptomus (Copepoda). Limnol Oceanogr 24:38-55

Haury LR, Yamazaki H, Itsweire EC (1990) Effects of turbulent shear flow on zooplankton. Deep-Sea Res 37:447-461

Hays GC (1995) Zooplankton avoidance activity. Nature 376:650

Hays GC, Proctor CA, John AWG, Warner AJ (1994) Interspecific differences in the diel vertical migration of marine copepods: the implications of size, color, and morphology. Limnol Oceanogr 39:1621-1629

Hempel G, Weikert H (1972) The neuston of the subtropical and boreal north-eastern Atlantic Ocean. A review. Mar Biol 13:70-88

Herring PJ (1965) Blue pigment of a surface-living oceanic copepod. Nature 205:103-104

Ianora A, Santella L (1991) Diapause embryos in the neustonic copepod Anomalocera patersoni. Mar Biol 108: 387-394

Incze LS, Hebert D, Wolff N, Oakey N, Dye D (2001) Changes in copepod distribution associated with increased turbulence from wind stress. Mar Ecol Prog Ser 213:229-240
Large WG, Pond S (1981) Open ocean momentum flux measurements in moderate to strong winds. J Phys Oceanogr 11:324-336

Lewis PV, Peters DS (1994) Diet of juvenile Atlantic menhaden in estuarine and coastal waters. Trans Am Fish Soc 123:803-810

Lillelund K, Lasker R (1971) Laboratory studies of predation by marine copepods on fish larvae. Fish Bull Fish Wildl Serv US 69:655-667

McCrary AB (1978) The life cycle of Anomalocera ornata Sutcliffe in North Carolina waters. ASB Bull 2:91 (Abstract)

Miller JM, Reed JP, Pietrafesa LJ (1984) Patterns, mechanisms, and approaches to the study of estuarine dependent fish larvae and juveniles. In: McCleave JD, Arnold GP, Dodson JJ, Neill WH (eds) Mechanisms of migration in fishes. Plenum Press, New York, p 209-255

Neill WE (1992) Population variation in the ontogeny of predator-induced vertical migration of copepods. Nature 356:54-56

Ohman MD (1990) The demographic benefits of diel vertical migration by zooplankton. Ecol Monogr 60:57-281

Ohman MD, Frost BW, Cohen EB (1983) Reverse diel vertical migration: an escape from invertebrate predators. Science 220:1404-1407

Osgood KE, Frost BW (1994) Ontogenetic diel vertical migration behaviors of the marine planktonic copepods Calanus pacificus and Metridia lucens. Mar Ecol Prog Ser 104:3-25

Reintjes RW (1969) Synopsis of biological data on the Atlantic menhaden, Brevoortia tyrannus. FAO Species Synop 42:30

Ringelberg J (1999) The photobehavior of Daphnia spp. as a model to explain diel vertical migration in zooplankton. Biol Rev 74:397-423

Sherman K (1963) Pontellid copepod distribution in relation to surface water types in the central north Pacific. Limnol Oceanogr 8:214-227

Sherman K (1964) Pontellid copepod occurence in the central south Pacific. Limnol Oceanogr 9:476-484

Sherman K, Schaner E (1968) Pontellid copepods as indicators of an oceanic incursion over Georges Bank. Ecology 49: $582-584$

Sutcliffe WH (1949) A new species of calanoid copepod from North Carolina. J Elisha Mitchell Sci Soc 65:273-275

Turner JT (1991) Zooplankton feeding ecology: do co-occurring copepods compete for the same food? Rev Aquat Sci 5: 101-195

Turner JT, Collard SB (1980) Winter distribution of pontellid copepods in the neuston of the eastern Gulf of Mexico continental shelf. Bull Mar Sci 30:526-529

Turner JT, Collard SB, Wright JC, Mitchell DV, Steele P (1979) Summer distribution of pontellid copepods in the neuston of the eastern Gulf of Mexico continental shelf. Bull Mar Sci 29:287-297

Turner JT, Tester PA, Hettler WF (1985) Zooplankton feeding ecology: a laboratory study of predation on fish eggs and larvae by the copepods Anomalocera ornata and Centropages typicus. Mar Biol 90:1-8

Vaissière R (1961) Morphologie et histologie comparées des yeux des crustacés copépodes. Arch Zool Exp Gén 100: $1-125$

Wiebe PH, Burt KH, Boyd SH, Morton AW (1976) A multiple opening/closing net and environmental sensing system for sampling zooplankton. J Mar Res 34:313-326

Wilson CB (1932) The copepods of the Woods Hole region Massachusetts. United States Government Printing Office, Washington, DC

Zar JH (1999) Biological statistics, 4th edn. Prentice Hall, Upper Saddle River, NJ

Submitted: July 17, 2003; Accepted: November 17, 2003

Proofs received from author(s): March 2, 2004 